This item was submitted to Loughborough's Research Repository by the author.

Items in Figshare are protected by copyright, with all rights reserved, unless otherwise indicated.

\title{
Match making and match breaking: the nature of match within and around job design
}

PLEASE CITE THE PUBLISHED VERSION

http://dx.doi.org/10.1348/096317909X485144

PUBLISHER

(c) British Psychological Society

VERSION

AM (Accepted Manuscript)

LICENCE

CC BY-NC-ND 4.0

\section{REPOSITORY RECORD}

Daniels, Kevin, and Jan De Jonge. 2019. "Match Making and Match Breaking: The Nature of Match Within and Around Job Design". figshare. https://hdl.handle.net/2134/6367. 
This item was submitted to Loughborough's Institutional Repository (https://dspace.lboro.ac.uk/) by the author and is made available under the following Creative Commons Licence conditions.

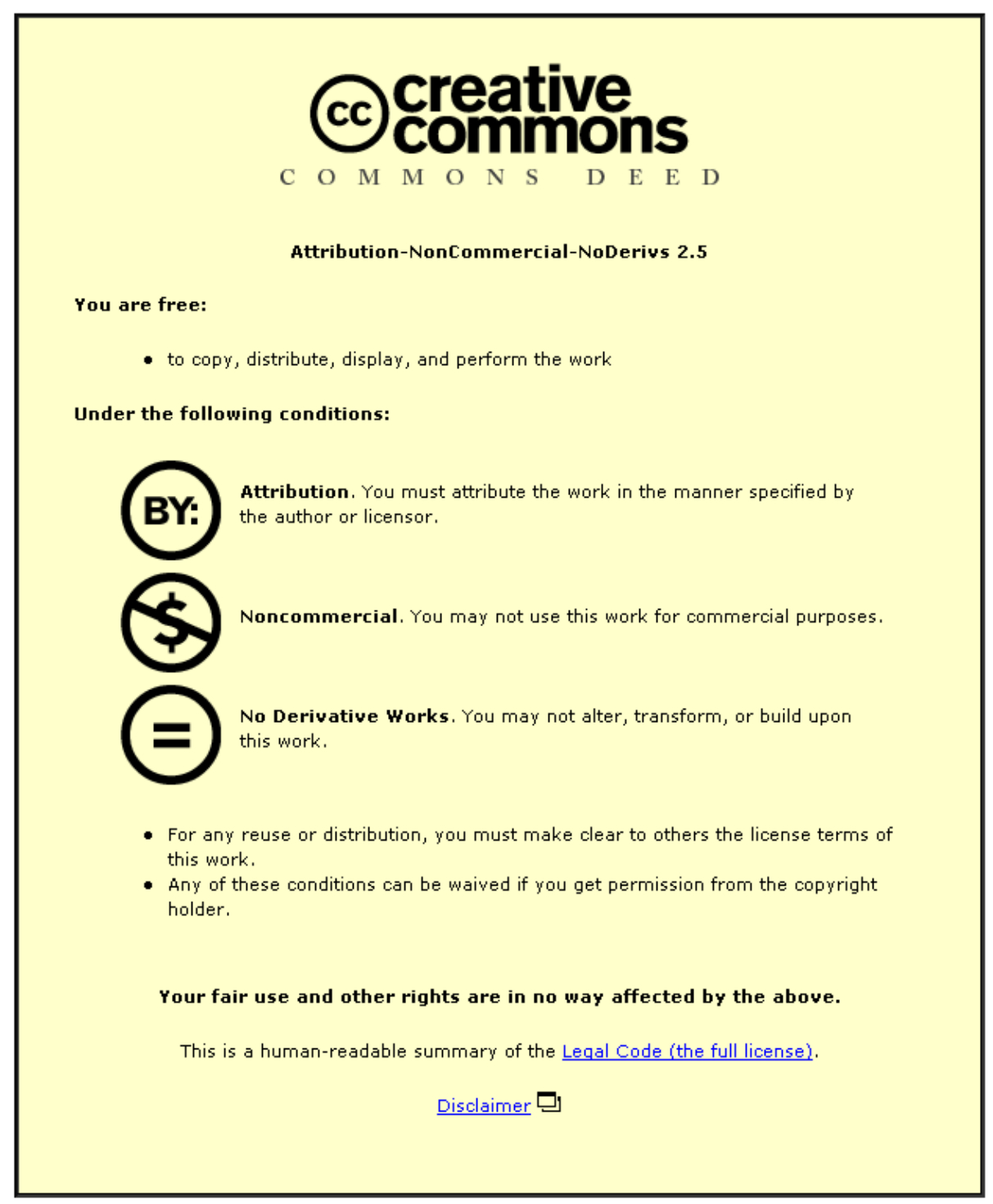

For the full text of this licence, please go to: http://creativecommons.org/licenses/by-nc-nd/2.5/ 
Match-Making and Match-Breaking:

\section{The Nature of Match Within and Around Job Design}

Kevin Daniels ${ }^{1}$, Jan de Jonge ${ }^{2}$

${ }^{1}$ Loughborough University

${ }^{2}$ Eindhoven University of Technology

Journal of Occupational and Organizational Psychology, 83, 1-16.

Word count (exc. figures/tables): 6033

*Requests for reprints should be addressed to Kevin Daniels Business School, Loughborough University, Leicestershire, LE11 3TU, United Kingdom. Email: k.j.daniels@lboro.ac.uk.

Acknowledgements: Kevin Daniels' contribution to this work has been supported by grants from the East Midlands Development Agency and the Engineering and Physical Sciences Research Council (EP/D04863X/1 and EP/F02942X/1). Jan de Jonge's contribution has been supported by a grant from the Japan Society for the Promotion of Science (S-09118) 
Match-Making and Match-Breaking:

The Nature of Match Within and Around Job Design

\begin{abstract}
We explore the notion of 'match'. In the context of job design, this is congruence or correspondence between two or more job characteristics (e.g., cognitive demands and cognitive control). This congruence is thought to benefit health, well-being and performance. The origins of the match concept lie in buffering models of work stress, where resources such as workplace social support and job control are thought to attenuate deleterious effects of adverse job characteristics like excessive job demands. We outline the historical developments in work stress research that has led to notions of match, contrast match with the related concept of person-environment fit, explore current conceptualisations and operationalisations of match, and outline how the concept of match can be developed.
\end{abstract}


Many areas of research and application in and around Work and Organisational Psychology are predicated on models that suggest the benefits of match, fit, congruence or correspondence between different phenomena (cf. Ostroff \& Schulte, 2007). For example, Holland's (1985) theory of career choice suggests certain people with certain vocational personality types (e.g., artistic) are more likely to be satisfied and successful in careers that match that personality type (e.g., such of those in the creative industries). Similarly, the discipline of ergonomics is concerned with ensuring technologies are designed to be suited to the physical and cognitive characteristics of the users of those technologies (Salvendy, 1998). In the area of work stress, person-environment fit theory indicates that people are likely to be more satisfied when what a job supplies (e.g., control) is what a person wants or desires, or where a person's abilities meet the demands of the job (e.g., Edwards, 1991; French, Caplan \& Harrison, 1982). A basic idea behind such models is that congruence, complementarity or supplementarity between two or more phenomena promotes performance, development, positive attitudes and well-being.

In contrast, within the area of job design and work stress, research has largely attempted to establish broad parameters of job design that are universally applicable (e.g., Demerouti, Bakker, Nachreiner, Friedhelm \& Schaufeli, 2001; Hackman \& Oldham, 1980; Karasek \& Theorell, 1990; LePine, Podsakoff \& LePine, 2005; Siegrist, 1998). For example, according to the Demands-Control-Support Model (DCSM), stressful work is characterised by high work demands, low job control and low social support. Such a universal approach to job design has been very successful, both in terms of an influence on research and in influencing practice. For example, Karasek and Theorell's review of the DCSM has been cited over 3700 times and Hackman and Oldham's account of the Job Characteristics Model (JCM) over 3000 times (Google Scholar, accessed $7^{\text {th }}$ December, 2009). Practically, for example, the UK Health and Safety Executive's Management Standards for Work-Related 
Stress provide guidance broad job characteristics that organisations should assess, and if necessary, change, to prevent stress in the work place (MacKay, Cousins, Kelly, Lee \& McCaig, 2004). This guidance is based on a review of the evidence on relationships between health and the kind of broad job features as those included in the DCSM and JCM (Rick, Thomson, Briner, O’Regan \& Daniels, 2002).

One particular line of enquiry concerns interactions between job features that are meant to enhance health or well-being (sometimes known as job resources, particularly job control and social support) and those meant to be detrimental to health or well-being (often known as job stressors, e.g., demands). The idea behind such tests is that broad job characteristics like job control or social support enable people to cope better with stressful work conditions, so that job control and social support buffer the detrimental effects of stressors (see especially Karasek \& Theorell, 1990). This is practically as well as theoretically important. Job demands, like high work pace or problem-solving demands, might be harmful to health and well-being but they may be beneficial to productivity or innovation. Moreover, jobs that are inherently risky, such as those on offshore oil platforms, may bring with them psychological effects such as worry. Therefore, if it can be demonstrated that some job characteristics can eliminate the harmful effects of other job characteristics that may be impossible or undesirable to design out of a job, then there is a basis for redesigning these jobs at least to eliminate their negative effects. Practically then, because job demands can often not be reduced, the idea of increasing job resources instead to combat strain is appealing.

Reviews of the extensive research base in this area indicate that it is main effects, not interactions, which characterise the evidence (de Lange, Taris, Kompier, Houtman, \& Bongers, 2003; van der Doef \& Maes, 1999). However, in the social support literature, it has been argued that the stress buffering effects of social support are most likely to be found 
where targeted and specific measures of support are used, rather than broad measures of social embeddedness (Cohen \& Wills, 1985; Viswesvaran, Sanchez, \& Fisher, 1999). The idea that measures of job characteristics need to be more specific and targeted, and the practical imperative of findings ways to attenuate the harmful effects of work stressors, has opened two avenues in relation to 'match'. Both are concerned with the level of specificity in measures of job characteristics, but differ in their approach to match.

The first avenue is concerned with establishing the level of specificity needed in measures of job characteristics needed to demonstrate buffering effects. This is typified in the Demand-Induced Strain Compensation (DISC) Model (de Jonge \& Dormann, 2003; 2006). Here 'match' refers to the match between specific forms of job demands, specific forms of job resources and specific forms of strain. The idea here is that job resources enable better coping with job demands where the resources match the demands and the type of well-being to be protected. For example, the DISC Model predicts emotional resources (e.g., emotional support) are most effective when deployed in protecting emotional well-being against the impact of emotional demands. In this approach, the focus of empirical interest is on relationships between indices of well-being on the one hand and 'matching', 'less-matching' and even 'non-matching' job characteristics on the other. Coping is not directly measured, but occupies a theoretical position as a mediator between matching job characteristics and indices of well-being.

The second avenue concerns specifying the form of coping specific job resources like social support and job control are used for, since job resources can be deployed for multiple purposes (Daniels, Harris \& Briner, 2004). For example, job control can be used to reschedule activities to spend more time resolving problems caused by a work stressor (problem-focused coping) or to engage in activities that distract the individual from the work stressor (avoidant coping). Here 'match' is defined in terms of 'matching' a specific job characteristic used for 
specific coping activities in relation to a specific stressor. In this approach, 'match' is treated more as a theoretical given. Coping is assessed, and relationships between 'matched' coping processes and other phenomena are the prime focus of empirical interest.

In the rest of this paper, we will briefly describe research on both approaches to match and consider how the concept of match can be broadened. First, we will consider similarities and differences with the closely related area of person-environment fit.

\section{Match and person-environment fit}

An obvious point of comparison and contrast for research on match is the personenvironment (P-E) fit perspective, because P-E fit is an influential approach to work stress research (Edwards, 1991; French et al., 1982; Ostroff \& Judge, 2007) and match principles are derived to explain parts of the stress process. On a surface level, both P-E fit and match concern how two or more concepts combine to influence a third concept.

P-E fit researchers have made distinctions between fitting the abilities of a person to the demands of a job, the desires of a person for those things that the job or organisation can supply, and similarity between the person and the organisation (see e.g., Kristoff, 1996; Muchinsky \& Monahan, 1987). In contrast, match is concerned with match between different aspects of job design, and so the focus is not so much on individual differences but on the work environment. As an area of investigation concerned with finding situations within which individuals can cope more effectively with work stressors, match research would also seem to be concerned with demands-abilities fit, or the abilities that some job characteristics (e.g., control) afford individuals to cope with stressors inherent in their work (e.g., psychological demands).

A more subtle distinction between the two perspectives might reflect the mode of fit as well as the stage each process occupies in the development of strain or well-being. P-E fit models based on fit between individual desires or values and characteristics of the 
environment may reflect more closely primary appraisal, that is the judgement concerning whether a situation has adverse consequences for an individual's goals or well-being (Lazarus, 1999). P-E fit models based on fit between an individual's abilities and demands of the situation may reflect either primary appraisal, or secondary appraisal, the choice of coping options (Lazarus, 1999). This has also been called person-person (PP) fit (Ostroff \& Schulte, 2007) and reflects a person-based view of the environment. In contrast, to date, match research asserts that the E variables should be conceptualised as situational characteristics, distinct from stable $\mathrm{P}$ variables. Fit to the environment based on situational characteristics can be called situation-situation (SS) fit (see also Ostroff \& Schulte, 2007). Further, match research has also been concerned with coping: Coping is either invoked as an explanatory principle in the 'black box' of the stress process (Chrisopoulos, Dollard, Winefield \& Dormann, this volume; de Jonge \& Dormann, 2006); or coping is assessed directly (Daniels \& Harris, 2005; Daniels, Beesley, Cheyne \& Wimalasiri, 2008).

Despite surface-level similarities and differences between P-E fit and match research, there is one area of overlap between the two perspectives. In P-E fit research, measures of personal and environmental characteristics should be commensurable (Edwards, 1991). That is, the same content dimensions need to be assessed in order to calculate the extent of fit. For example, individual preferences for team working should be assessed using similar items to those used to assess levels of team working experienced. Incommensurable measures might assess levels of team working with one set of items, and assess preferences for team working indirectly through a personality index of affiliation needs, for example. Commensurable measures have a number of mathematical properties that make them attractive to P-E fit researchers, but also reflect the underlying principles of P-E fit research and provide a powerful basis for examining the consequences of P-E fit. (Edwards, 1991; Ostroff \& Judge, 2007). 
Although such arguments have not been articulated in the same way in match research, there is a similar notion of specificity of measurement, either ensuring measures of resources are specific to stressors assessed or assessing coping as enacted through specific resources in relation to specific stressors. The ideas here are that specific measures provide a better basis for uncovering the stress-buffering effects of job resources (Chrisopoulos et al., this volume; de Jonge \& Dormann, 2006) or provide a better basis for examining how job resources facilitate specific forms of coping (Daniels, Boocock, Glover, Hartley \& Holland, 2009; Daniels \& Harris, 2005). In the following two sections, different approaches to specificity in match research will be described.

\section{Match and buffering models}

The Demand-Induced Strain Compensation (DISC) Model tries to unify principles that are common to current job stress models, and claims to be a more cohesive theoretical model of job stress. As the theoretical basis of the DISC Model, de Jonge and Dormann (2006) propose homeostatic regulation processes. To survive, a living organism must maintain certain critical parameters within a bounded range. For instance, the human body must regulate its temperature, amount of fluids, and energy level. Maintaining each critical parameter requires that the body come into contact with the corresponding satiatory stimulus (i.e., clothes, water, and food) at the right time. The process by which these critical parameters are maintained is generally referred to as homeostatic regulation. For instance, in the area of immune functioning, homeostatic regulation processes are known to cause an activation of internal resources (e.g., hormones, neurotransmitters, and lymphocytes) when particular demands occur (Lekander, 2002). Through evolutionary processes, the release of functional, matching internal resources is more likely than the release of dysfunctional, non-matching immune parameters (Lekander, 2002). Similar homeostatic regulation processes can be found in the nervous system as well. For example, homeostatic regulation processes engage the fine 
scale organisation and operation of volumes of neural tissue to provide powerful and functional resources for neural signal integration and stable long-term storage of information (Montague, 1996).

The idea of functional homeostatic regulation can be transferred to organisational settings (e.g., Vancouver, 2000). Functional homeostatic regulation at work involves self-regulation processes whose function is to cope with states of psychological imbalance induced by job demands (cf. Pomaki \& Maes, 2002). Thus, similar to homeostatic regulation in the immune system and nervous system, in the DISC Model, it is proposed that individuals activate functional, corresponding job-related resources to mitigate the effects of specific job demands. Basically, a match exists if an external resource provides a function similar to that of an internal resource when combating stress. For example, when emotional problems with customers arise (e.g., insolent customers), an emotional self-regulation capability is likely to be quite helpful. When individuals lack this internal resource, emotionally supportive colleagues may do an almost similarly effective job. Even if supportive colleagues are unavailable, other job resources can be useful to some extent, such as information provided by a supervisor about how to handle a certain troublesome customer. DISC proposes that demands are first dealt with by attempting to turn to easily available internal resources. If these resources are depleted, a demand for matching external resources is created, which may be of similar use (cf. Hobfoll, 2002). If such matching external resources are not available or if they are depleted, individuals search for other resources. They will then use even those resources that do not closely correspond to the demand (cf. Vohs, Baumeister, \& Ciarocco, 2005). Accordingly, it is internal, matching resources which are most powerful in combating demands (when present), followed by corresponding external resources, and then nonmatching external resources. 
The DISC Model is premised on several key principles. First, de Jonge and Dormann $(2003 ; 2006)$ emphasise the need to recognise the multidimensionality of the stress concepts used. They propose that job demands, job resources and job-related strains each contain cognitive, emotional and physical elements. As far as job demands are concerned, three types can be distinguished: (1) cognitive demands that impinge primarily on the human information processing (Hockey, 2000); (2) emotional demands, mainly concerning the effort needed to deal with organisationally desired emotions during interpersonal transactions (Morris \& Feldman, 1996); and (3) physical demands that are primarily associated with the muscularskeletal system (i.e., sensorimotor and physical aspects of behavior; cf. Hockey, 2000). Similarly, job resources may have a cognitive-informational component (e.g., colleagues providing information), an emotional component (e.g., colleagues providing sympathy and affection) and a physical component such as instrumental help of colleagues or ergonomic aids (cf. Cohen \& Wills, 1985; Cutrona \& Russell, 1990). Finally, in a similar vein to demands and resources, strains may also comprise cognitive, emotional and physical dimensions (cf. Koslowski, 1998; Le Blanc, de Jonge, \& Schaufeli, 2008). For instance, employee creativity and active learning represent cognitively laden outcomes (e.g., Amabile, 1996; Taris \& Kompier, 2005), emotional exhaustion ('burnout') represents an emotionally laden strain variable (e.g., Maslach \& Jackson, 1986), and physical health complaints can be reasonably assumed to mainly reflect bodily sensations.

Second, a key principle is the triple-matching of concepts (i.e., matching demands, resources and strains, cf. de Jonge \& Dormann, 2006). The idea of there being matches between job demands and job resources was first mentioned in Work and Organisational Psychology by Cohen and McKay (1984; see also Cohen \& Wills, 1985). They proposed that interaction effects were greatest when there was a match between specific kinds of job demands and certain forms of social support (as a job resource). For instance, instrumental aid 
from colleagues ('resource') may help reduce strain caused by heavy lifting ('demand'). De Jonge and Dormann call this correspondence between a demand and a resource a doublematch of common kind, because (1) the first two out of three constructs (i.e., demand, resource, strain) match, and (2) this kind of match between independent variables has been commonly proposed by several scholars in the field (e.g., Cohen \& Wills, 1985; Sargent \& Terry, 1998; Wall, Jackson, Mullarkey \& Parker, 1996). The double-match of common kind hypothesis has received some support (e.g., Terry, Nielsen, \& Perchard, 1993; Terry \& Jimmieson, 1999), but the overall evidence is mixed.

In the late 1990s, this match notion was extended by Frese (1999). He argued that the third component of the demand-resource-strain triad, that is, the strain component, should be considered as a source of match or non-match as well. More specifically, Frese proposed that this match occurs between job resources, on the one hand, and strain, on the other, which, in accordance with Frese's suggestion, de Jonge and Dormann labelled double-match of extended kind. In other words, the match is extended to the dependent variables, but is still a double-match (between two out of three constructs: resource and strain). For instance, social types of resources (e.g., support from colleagues) are supposed to function more regularly as a buffer in relation to social types of strain (such as social anxiety and irritation) than in relation to less social areas of strain (like physical symptoms; see also Dormann \& Zapf, 1999).

When such a double-match of extended kind is investigated, it is still a theoretical challenge to predict which type of job resource will mitigate the relation between job demands and job strain (e.g., Viswesvaran et al., 1999). However, based upon the abovementioned ideas regarding double-match of common kind, double-match of extended kind, and the multidimensionality of constructs, the triple-match principle (TMP) was developed (de Jonge \& Dormann, 2003; 2006). The TMP proposes that the strongest interactive effects of job demands and job resources are observed when demands, resources and strains are 
based on qualitatively identical dimensions. Therefore, the TMP suggests not only that demands and resources should match (i.e., double-match of common kind; cf. Cohen \& Wills, 1985), and that resources should match strains (i.e., double-match of extended kind; cf. Frese, 1999), but also that demands should match strains. For instance, insolent customers are more likely to cause emotional disorders than deficits in active learning or physical complaints. In other words, the TMP applies to two different levels: (1) the match between job demands and job resources; and (2) the match between job demands/resources and job strain outcomes.

De Jonge, Dormann and van den Tooren (2008) presented an overview of the evidence for the key assumptions in the DISC Model, which has been updated in this paper. Studies conducted to test the principles of the DISC Model show that results in general have been supportive. Fifteen out of nineteen DISC studies showed evidence in support of the TMP. It should be noted that in order to identify a triple-match in a regression analysis, the interaction term between similar demands and resources in the prediction of an identical outcome should be significant. Furthermore, thirteen cross-sectional studies support the DISC Model. Nine cross-sectional studies reported a significant triple-match interaction of either cognitive or emotional kind. In addition, four cross-sectional studies reported a significant triple-match interaction of physical kind. Finally, four cross-sectional studies were not supportive at all regarding triple-match interactions.

In regard to longitudinal studies, two two-wave panel studies among 280 and 267 health care workers, conducted by de Jonge and Dormann (2006), showed a significant interaction between baseline (high) physical demands and (low) physical resources in predicting physical health complaints two years later. In addition, they also detected a significant interaction between baseline (high) emotional demands and (low) emotional resources in predicting emotional exhaustion two years later. Chrisopoulos and associates (this volume) found empirical evidence for one out of three tested triple-match interactions 
(high cognitive demands and resources in predicting professional efficacy one year later) in their two-wave panel study among 179 police officers. Remarkably, the likelihood of finding interaction effects in these studies was nearly linearly related to the degree of match, with $33.3 \%$ of all tested interactions becoming significant when there was a triple-match, $18.5 \%$ significant interactions when testing for double-matches (common kind as well as extended kind), and $0.0 \%$ significant interactions when there was no match.

To conclude, results of DISC studies show in general that particular combinations of specific job demands and matching job resources have the highest predictive validity with regard to cognitive, emotional and physical outcomes, which is in line with the core propositions of the model. More specifically, 79\% of all DISC studies reported showed evidence in support of the triple-match principle.

\section{Coping and match}

De Jonge and Dormann's DISC model is based on the premise that the stress buffering effects of job resources are dependent on specific resources being available to cope with specific demands in order to protect specific forms of well-being. Another line of enquiry has been based on the premise that the stress buffering effects of job resources are evident only when accompanied by predispositions to use coping targeted at resolving problems caused by stressful circumstances. This line of enquiry is based on the notion that resources such as job control and social support enable problem-focused coping and problem-focused coping is the most effective form of coping (e.g., Karasek \& Theorell, 1990).

A number of studies have indicated that both job control and social support buffer the effects of work stressors only for those people for who it is reasonable to assume will be predisposed to problem-focused coping (e.g., hardiness, Maddi \& Kobassa, 1984; internal locus of control, Daniels \& Guppy, 1994, Meier, Semmer, Elfering \& Jacobshagen, 2008; self-determination, Fernet, Guay \& Senécal, 2004; self-efficacy, Parker \& Sprigg, 1999, 
Schaubroeck \& Merritt, 1997, Schaubroeck, Jones \& Xie, 2001). Other studies have found that job control and support demonstrate stress buffering effects only for people who report using more problem-focused coping (Daniels, 1999; de Rijk, Le Blanc, Schaufeli, \& de Jonge, 1998; Shimazu, Shimazu \& Odara, 2005; Shimazu, de Jonge \& Irimajiri, 2008).

However, there are a number of complications. First, other forms of coping, such as avoidance, may be beneficial if combined with job resources such as control and support (Daniels, 1999), weakening the claim that job resources facilitate the effectiveness of problem-focused coping only. Also, a number of studies indicate that job resources can accentuate rather than attenuate the effects of job stressors (Buunk \& Hoorens, 1992; Kaufman \& Beehr, 1986; Mullarkey, Jackson, Wall, Wilson \& Grey-Taylor, 1997; Sargent \& Terry, 1998), suggesting that job resources such as control and support may lead people to use ineffective or even harmful coping strategies, as well as a variety of more effective strategies. Third, all of the research that suggests problem-focused coping acts as a third moderator of job stressors, alongside job resources, is based either on an assumption that individual differences are associated with problem-focused coping or generalised assessments of coping based that do not reflect coping as it happens.

These problems reflect important developments in the coping and job design literatures. First, coping is not merely the function of coping (e.g., problem-focused, avoidance), but reflects behaviours used to enact those functions and resources that enable the behaviours (Latack \& Havlovic, 1992; Latack, Kinicki \& Prussia, 1995; Lazarus, 1999; Skinner, Edge, Altman \& Sherwood, 2003; Schönpflug \& Battmann, 1988). Neglect of any aspect of these aspects of coping leads to an incomplete picture of the coping process (cf. Skinner et al., 2003). Second, both coping (Lazarus, 1999) and job characteristics (Clegg \& Spencer, 2007; Daniels, 2006) are dynamic phenomena that can change rapidly. In the coping literature, this has led to methodological developments in which the most accurate assessments of coping are those that 
capture coping over short periods close to when coping happens (Tennen, Affleck, Larsen, Coyne \& DeLongis, 2006). For example, coping activity assessed several times per day gives a more accurate picture than daily retrospective reports, in turn, coping activity assessed once a day over a week gives a more accurate picture than weekly retrospective reports. In the job design literature, the recognition that job characteristics are dynamic has led to suggestions that job characteristics comprise enacted aspects (Clegg \& Spender, 2007; Daniels, 2006), and the enactment of job characteristics can be purposive (Wrzesniewski \& Dutton, 2001).

Bringing developments in the coping and job design literatures together, it may be suggested that job resources such as job control and social support are enacted for specific coping purposes in relation to specific stressors as the stressors occur (Daniels et al., 2004). This ties coping functions, to coping behaviours and coping resources, through the enactment (behaviour) of a specific job characteristic (resource) to fulfil a specific coping function. It also enables us to see how job resources might be used to fulfil multiple coping functions. For example, the enactment of job control to deal with a specific stressor may entail rescheduling activities to spend more time on seeking a solution that will remove the stressor (problemfocused coping), rescheduling activities to engage in other forms of work to distract oneself from the problem (avoidant coping) or rescheduling breaks to allow emotional venting in response to a stressor away from the normal workplace. To capture coping and job characteristics as they are enacted in response to stressors, research has also started to use daily (Daniels \& Harris, 2005) and hourly reports of coping (Daniels et al., 2008, 2009).

It is worth noting that this line of research, like de Jonge and Dormann, ties resources to specific stressors. Unlike de Jonge and Dormann, specific job characteristics are assessed directly for how they are used for specific coping functions. In three studies, participants have been asked to indicate the extent to which they had experienced researcher-defined stressors (generalised demands, Daniels \& Harris, 2005, problem-solving demands, Daniels et al., 
2008, 2009). Then participants were asked to indicate the extent to which they had used job control or social support in order to fulfil specific coping functions in relation to the predefined stressor.

Studies have found that both job control and support enacted for problem-focused coping are associated with indicators of well-being and cognitive performance, but these relationships are qualified by either the time course of coping and/or the precise measure of well-being (Daniels \& Harris, 2005; Daniels et al., 2008). Other forms of coping enacted by control and support, for instance avoidance and affective expression, were also found to be related to indicators of well-being and cognitive performance. In two samples, Daniels et al. (2009) found some support for Karasek and Theorell's active learning hypothesis of the DCSM (1990), in which learning is hypothesised to mediate the effects of job control and support enacted to solve problems on well-being. Consistent with de Jonge and Dormann (2006), the cognitive variable of learning was related to resources used for cognitive oriented coping (problem-solving) in response to a cognitive stressor (problem-solving demands). Learning was related to greater experience of positive affect.

Other than work on job control and support enacted for problem-solving which has been linked to specific theoretical processes embedded in Karasek and Theorell's DCSM, research has yet to work out how specific coping functions enacted through specific resources enable different forms of adaptation. For example, enacting job control to avoid stressors temporarily, such as rescheduling activities to do effortless rather than demanding tasks, may lead to feelings of recovery from demanding work (cf., Sonnentag \& Zijlstra, 2006). Enacting social support to express affect to cope with a stressor may lead to strengthening of social ties in a work group (Rimé, 2007), whereas enacting job control to express affect, such as taking an unscheduled break to express affect in private may not strengthen social ties, but may 
allow the stressor's detrimental affective, cognitive, and physiological effects to diminish quickly (Austenfeld \& Stanton, 2004).

Van den Tooren and de Jonge (this volume) indicate that it is important to look inside the 'black box' of job stress. Examining how job characteristics are enacted for specific coping functions entails looking at one area inside the 'black box'; however, this line of research has yet to address why certain coping functions might be enacted through certain job resources. Van den Tooren and de Jonge indicate that the availability and relevance of job resources might be important when these resources match the job demands to be coped with. However, they also indicate non-matching resources might be perceived favourably, which might reflect whether an individual seeks problem-resolution, recovery, reaffirmed social ties or catharsis in a stressful situation. However, there might be other influences on the choice of which resource to enact and for which purpose (Daniels et al., 2004). For example, an individual might choose to enact job control to engage in problem-focused coping if s/he is focused on maximising benefits for him/herself from successful coping, or choose to enact social support to engage in problem-focused coping if $s /$ he is focused on minimising the chance of ineffective coping by getting the views of others (cf., Higgins, 1997).

\section{Moving match forward}

As well as specific issues concerning specific approaches to match, outlined above, there are other areas where research on the match principle can be developed. Limited space allows us to give a few suggestions of match research only. The first of these concerns integrating multiple levels of analysis into research. A study by Molleman, Broekhuis, Stoffels and Jaspers (this volume), for example, showed that not only matches at the job level should be considered, but also at the level of the various tasks within a job because task characteristics such as component complexity may vary from client to client and from product to product.

Furthermore, there is a long established line of argument that organisations should seek to 
match divergent elements of human resource management practices, including job design, in order to derive coherent bundles of practices that can enhance organisational performance (Wood, 1999). Research also indicates that human resource management practices evolve so that they 'match' or 'fit' with other organisational features or organisational environments (Patterson, West \& Wall, 2004; Toh, Morgeson \& Campion, 2008). There is also evidence that where aspects of job design do not match features of organisational environments, then any benefits from well-designed jobs may be eroded (Daniels, Tregaskis \& Seaton, 2007). Research on P-E fit also indicates that the predictive ability of fit may depend on economic and cultural factors at the level of the state (Nyambegera, Daniels \& Sparrow, 2001). Therefore, it might be fruitful to examine how organisational and supra-organisational factors influence the viability of different forms of match.

Another level of analysis concerns time, and differentiating between acute and enduring situations where there is some level of match. One study has investigated the effects of acute and enduring job demands on acute strains in medical emergency staff (Gevers, van Erven, de Jonge, Maas \& de Jong, 2009). Results showed that acute demands are more likely to result in acute strain when matching enduring demands are also experienced to be high. In addition, research using repeated measurements of hourly and daily coping activity has demonstrated that coping functions enacted through specific job resources may have variable effects, depending on the duration for which coping activity is sustained (Daniels \& Harris, 2005; Daniels et al., 2008). Therefore, the role that time plays deserves further attention. For example, it may be that people can tolerate short periods of mismatch, but not longer periods of mismatch; the harmful effects of short periods of mismatch are accentuated under conditions of chronic mismatch; or that there needs to be sustained enactment of some job characteristics in order for some coping functions to be beneficial. 
One potential corollary of match is that people will seek out match because it enables effective coping. It may not necessarily be the case that people always seek match. If people can tolerate periods of mismatch, then perhaps some individuals may seek out mismatches in order to develop their coping abilities and resources. However, this may be an unlikely scenario, since it may be more likely that effective coping will lead to an accumulation of job resources to enact for coping (Hobfoll, 2001), so that match should lead to an accumulation of job resources like autonomy and support. Other processes may indicate match can lead to an accumulation of job and other resources. For example, the finding that job control and support enacted for problem-solving leads to learning (Daniels et al., 2009) indicates how processes underpinning match can lead to an increase in cognitive repertoires and enable more effective problem-solving in future circumstances (Karasek \& Theorell, 1990).

Like the accumulation of job resources, match might be related to a range of other variables other than well-being and strain. For example, de Jonge and Peeters (2009) found that interactions between matching job demands and resources were more likely to predict counter-productive work behaviour than non-matching interactions, which was true for both self-reports and co-worker reports. Similarly, Molleman and colleagues (this volume) have argued that different job characteristics may make different matches manifest. For instance, high component complexity makes manifest a complementary fit of expertise, whereas interrelatedness brings to the surface any supplementary mismatch of professional values and identities. Moreover, their study shows that multiple (mis)matches may exist simultaneously and should be considered simultaneously.

It may be the case that the match principle is relevant to any situation in which workers need to deploy job resources in order to cope with or otherwise adjust to job demands, that is where individuals self-regulate. Motivation and the choice of work goals in one obvious area of self-regulation that might be relevant to aspects of job design (Parker \& Ohly, 2008). Another example relates to creativity and innovation, both of which may be 
influenced by problem-solving (Scott \& Bruce, 1994). Creativity and innovation may be more likely where people are able to enact job resources suitable for solving problems they encounter in their work (e.g., de Jonge, Le Blanc, Peeters \& Noordam, 2008).

Finally, Sonnentag and Zijlstra (2006) have noted that the process of recovering from job demands is equally important as the role of job resources. In line with Meijman's (1989) Effort-Recovery Model and subsequent theorising about the role of recovery in the job stress process (Geurts \& Sonnentag, 2006), it is proposed that off-job recovery from work has an additional, synergistic, effect in the relation between job demands, job resources and employee outcomes. Moreover, Sonnentag and colleagues (e.g., Sonnentag \& Natter, 2004; Sonnentag \& Niessen, 2008) noticed that most recovery research did not encompass all dimensionalities of off-job recovery. In this respect, recovery from work should encompass cognitive, emotional and physical detachment from work, and off-job recovery from within the same domain as the job demands (e.g., cognitive, emotional, or physical) may produce a greater likelihood of counteracting the negative job demands and create optimal conditions for health and performance (de Jonge, Spoor, Dormann, Sonnentag \& van den Tooren, 2009). Similarly, recovery may happen within the work day through breaks (Trougakos, Beal, Green $\&$ Weiss, 2008), and the role of enacting certain job characteristics to facilitate recovery within the work day may warrant further attention (Daniels, in press).

\section{Conclusion}

Match is an approach to job design predicated upon the notion that coping with the demands of work is dependent upon having suitable and specific resources available to enact suitable and specific coping functions. Starting from a problem with detecting interactions between broad measures of job resources and broad measures of job stressors, research on match has been concerned with determining the best circumstances in which to observe interactions between job resources and job demands or with how job characteristics are 
enacted for different coping functions. However, these need not be the only approaches to examining match, as van den Tooren and de Jonge (this volume), Molleman et al. (this volume) and de Jonge et al. (2009) indicate. Research into match has primarily been concerned with one aspect of self-regulation - coping with work demands and stressors. However, match as a principle in job design need not be limited to this area of regulation, and the match principle may be relevant to using job design to promote other areas of selfregulation. For instance, not only match-making but also match-breaking (i.e. recovery opportunities at/after work) seems to be an interesting avenue for future research. Notwithstanding, within its main area of focus, research on different aspects of match has indicated a detailed appreciation is needed of how jobs are configured and enacted if job design research is to build upon its rich heritage of research and intervention to protect workers' well-being and health as well as to optimise job performance. 


\section{References}

Amabile, T.M. (1996). Creativity in context. Update to the social psychology of creativity. Colorado: Westview Press.

Austenfeld, J.L., \& Stanton, A.L. (2004). Coping through emotional approach: A new look at emotion, coping, and health-related outcomes. Journal of Personality, 72, 1335-1363.

Buunk, B.P., \& Hoorens, V. (1992). Social support and stress: The role of social comparison and social exchange processes. British Journal of Clinical Psychology, 31, 445-457.

Chrisopoulos, S., Dollard, M.F., Winefield, A.H., \& Dormann, C. (this volume). Increasing the probability of finding an interaction in work-stress research: A two wave longitudinal test of the triple-match principle. Journal of Occupational and Organizational Psychology.

Clegg, C.W., \& Spencer. C. (2007). A circular and dynamic model of the process of job design. Journal of Occupational and Organizational Psychology, 80, 321-339.

Cohen, S., \& McKay, G. (1984). Social support, stress and the buffering hypothesis: A theoretical analysis. In A. Baum, S.E. Taylor, \& J.E. Singer (Eds.), Handbook of Psychology and Health (pp. 253-267). Hillsdale, NJ: Erlbaum.

Cohen, S., \& Wills, T.A. (1985). Stress, social support, and the buffering hypothesis. Psychological Bulletin, 98, 310-357.

Cutrona, C.E., \& Russell, D.W. (1990). Type of social support and specific stress: Toward a theory of optimal matching. In B.R. Sarason, I.G. Sarason \& G.R. Pierce (Eds.), Social Support: An Interactional View (pp. 319-366). New York: Wiley \& Sons.

Daniels, K. (1999). Coping and the job demands-control-support model: an exploratory study. International Journal of Stress Management, 6, 125-144.

Daniels, K. (2006). Rethinking job characteristics in work stress research. Human Relations, 59, 267-290. 
Daniels, K. (in press). Stress and well-being are still issues and something still needs to be done: Or why agency and interpretation are important for policy and practice. In G.P.Hodgkinson and J.K.Ford (Eds.), International Review of Industrial/Organizational Psychology (volume 26). Chichester: Wiley.

Daniels, K. \& Guppy, A. (1994). Occupational stress, social support, job control and psychological well-being. Human Relations, 47, 1523-1544.

Daniels, K., Beesley, N.J., Cheyne, A.J.T. \& Wilmarisiri, V.P. (2008). Coping processes linking the Demands-Control-Support model, affect, and risky decisions at work. Human Relations, 61, 845-874.

Daniels, K., Boocock, G., Glover, J., Hartley, R. \& Holland, J. (2009). An experience sampling study of learning, affect, and the Demands Control Support model. Journal of Applied Psychology, 94, 1003-1017.

Daniels, K. \& Harris, C. (2005). A daily diary study of coping in the context of the job demands-control-support model. Journal of Vocational Behavior, 66, 219-237.

Daniels, K., Harris, C. \& Briner, R.B. (2004). Linking work conditions to unpleasant affect: cognition, categorisation and goals. Journal of Occupational and Organizational Psychology, 77, 343-364.

Daniels, K., Tregaskis, O. \& Seaton, J.S. (2007). Job control and occupational health: the moderating role of national R\&D activity. Journal of Organizational Behavior, 28, 120.

Demerouti, E., Bakker, A.B., Nachreiner, F., \& Schaufeli, W.B. (2001). The job demandsresources model of burnout. Journal of Applied Psychology, 86, 499-512.

Doef, M., \& Maes, S. (1999). The job demand-control(-support) model and psychological well-being. Work and Stress, 13, 87-114. 
Dormann, C., \& Zapf, D. (1999). Social support, social stressors at work and depression: Testing for main and moderating effects with structural equations in a 3-wave longitudinal study. Journal of Applied Psychology, 84, 874-884.

Edwards, J.R. (1991). Person-job fit: A conceptual integration, literature review, and methodological critique. In C.L.Cooper \& I.T. Robertson (Eds.), International review of industrial/organizational psychology (Vol. 6, pp 283-357). Chichester: Wiley.

Fernet, C., Guay, F., Senecal, C. (2004). Adjusting to job demands: the role of work selfdetermination and job control in predicting burnout. Journal of Vocational Behavior, 65, $39-56$.

French, J.R.P. Jr, Caplan, R.D., \& Harrison, R.V. (1982). The mechanisms of job stress and strain. New York: Wiley.

Frese, M. (1999). Social support as a moderator of the relationship between work stressors and psychological dysfunctioning: A longitudinal study with objective measures. Journal of Occupational Health Psychology, 4, 179-192.

Geurts, S.A.E., \& Sonnentag, S. (2006). Recovery as an explanatory mechanism in the relation between acute stress reactions and chronic health impairment. Scandinavian Journal of Work, Environment, and Health, 32, 482-492.

Gevers, J.M.P., Erven van, P.M.J.N.L., Jonge de, J., Maas, M., \& Jong de, A.A.M. (2009). The effect of acute and chronic job demands on effective individual teamwork behaviour in medical emergencies. Revised manuscript submitted for publication. Hackman, J.R., \& Oldham, G.R. (1980). Work redesign. Reading, MA: Addison Wesley. Higgins, E.T. (1997). Beyond pleasure and pain. American Psychologist, 52, 1280-1300. Hobfoll, S.E. (2001). The influence of culture, community, and the nested-self in the stress process: Advancing the conservation of resources theory. Applied Psychology: An International Review, 50, 337-370. 
Hobfoll, S.E. (2002). Social and psychological resources and adaptation. Review of General Psychology, 6, 307-324.

Hockey, G.R.J. (2000). Work environments and performance. In N. Chmiel (Ed.), Introduction to Work and Organisational Psychology: A European Perspective (pp. 206-230). Oxford: Blackwell Publishers.

Holland J.L. (1985) Making vocational choices. Englewood Cliffs: Prentice Hall.

Jonge de, J., \& Dormann, C. (2003). The DISC Model: Demand-Induced Strain Compensation mechanisms in job stress. In M.F. Dollard, A.H. Winefield, \& H.R. Winefield (Eds.), Occupational stress in the service professions (pp. 43-74). London: Taylor \& Francis.

Jonge de, J., \& Dormann, C. (2006). Stressors, resources, and strain at work: A longitudinal test of the triple-match principle. Journal of Applied Psychology, 91, 1359-1374.

Jonge de, J., Spoor, E., Dormann, C., Sonnentag, S., \& Tooren, M. van den (2009). “Take a break?" Off-job recovery, job demands and job resources as predictors of active learning, creativity, and health. Manuscript submitted for publication.

Jonge de, J., Dormann, C., \& Tooren van den, M. (2008). The Demand-Induced Strain Compensation Model: Renewed theoretical considerations and empirical evidence. In K. Näswall, J. Hellgren, \& M. Sverke (Eds.), The individual in the changing working life (pp. 67-87). Oxford: Cambridge University Press.

Jonge de, J. \& Peeters, M.C.W. (2009). Convergence of self- and coworker-reports of counterproductive work behavior: A cross-sectional multi-source survey among health care workers. International Journal of Nursing Studies, 46, 699-707.

Jonge de, J., Le Blanc, P.M., Peeters, M.C.W., \& Noordam, H. (2008). Emotional job demands and the role of matching job resources: A cross-sectional survey study among health care workers. International Journal of Nursing Studies, 45, 1460-1469. 
Karasek, R.A., \& Theorell, T. (1990). Healthy work. New York: Basic Books.

Kaufman, G.M., \& Beehr, T.A. (1986). Interactions between job stressors and social support some counterintuitive results. Journal of Applied Psychology, 71, 522-526.

Koslowski, M. (1998). Modeling the stress-strain relationship in work settings. London: Routledge.

Kristoff, A.L. (1996). Person-organization fit: An integrative review of its conceptualisations, measurement, and implications. Personnel Psychology, 83, 139-149.

Lange, de A.H., Taris, T.W., Kompier, M.A.J., Houtman, I.R.D., \& Bongers, P.M. (2003). "The very best of the millennium": Longitudinal research and the demand-control(support) model. Journal of Occupational Health Psychology, 8, 282-305.

Latack, J.C., \& Havlovic, S.J. (1992). Coping with job stress: a conceptual evaluation framework for coping measures. Journal of Organizational Behavior, 13, 479-508.

Latack, J.C., Kinicki, A.J., \& Prussia, G.E. (1995). An integrative process model of coping with job loss. Academy of Management Review, 20, 311-342.

Lazarus, R.S. (1999). Stress and emotion: A new synthesis. New York: Springer.

Le Blanc, P.M., Jonge, de J., \& Schaufeli, W.B. (2008). Job stress and occupational health. In N. Chmiel (Ed.), An Introduction to Work and Organisational Psychology: A European Perspective (Second Edition) (pp. 119-147). Oxford: Blackwell Publishing.

Lekander, M. (2002). Ecological immunology: The role of the immune system in psychology and neuroscience. European Psychologist, 7, 98-115.

LePine, J.A., Podsakoff, N.P., \& LePine, M.A. (2005). A meta-analytic test of the challenge stressor-hindrance stressor framework: an explanation for inconsistent relationships among stressors and performance. Academy of Management Journal, 48, 764-775. 
MacKay, C.J., Cousins, R., Kelly, P.J., Lee, S. \& McCaig, R.H. (2004). 'Management Standards' and work-related stress in the UK: Policy background and science. Work \& Stress, 18, 91-112.

Maddi, S.R. \& Kobassa, S.C. (1984). The hardy executive: health under stress. Pacific Grove CA: Brooks/Cole.

Maslach, C., \& Jackson, S.E. (1986). Maslach Burnout Inventory: Manual (2nd ed.). Palo Alto, CA: Consulting Psychologists Press.

Meier, L.L., Semmer, N.K., Elfering, A., \& Jacobshagen, N. (2008). The double meaning of control: Three-way interactions between internal resources, job control, and stressors at work. Journal of Occupational Health Psychology, 13, 244-258.

Meijman, T.F. (Ed.) (1989). Mentale Belasting en Werkstress: Een Arbeidspsychologische Invalshoek [Mental load and workstress: A work psychological approach]. Assen: Van Gorcum.

Molleman, E., Broekhuis, M., Stoffels, R., \& Jaspers, F. (this volume). Complexity of healthcare needs and interactions in multidisciplinary medical teams. Journal of Occupational and Organizational Psychology.

Montague, P.R., (1996). The resource consumption principle: Attention and memory in volumes of neural tissue. Proceedings of the National Academy of Sciences of the United States of America, 93, 3619-3623.

Morris, J.A., \& Feldman, D.C. (1996). The dimensions, antecedents, and consequences of emotional labour. Academy of Management Review, 21, 986-1010.

Muchinsky, P.M. \& Monahan, C.J. (1987). What is person-environment congruence? Supplementary versus complementary models of fit. Journal of Vocational Behavior, $31,268-277$. 
Mullarkey, S., Jackson, P.R., Wall, T.D., Wilson, J.R., \& Grey-Taylor, S.M. (1997). The impact of technology characteristics and job control on worker mental health. Journal of Organizational Behavior, 18, 471-489.

Nyamberega, S., Daniels, K., Sparrow, P. (2001). Person-organization fit and job involvement in developing contexts. Applied Psychology: An International Review, 50, 109-140.

Ostroff, C. \& Judge, T.A. (Eds.) (2007), Perspectives on Organizational Fit. New York: Lawrence Erlbaum Associates.

Ostroff, C. \& Schulte, M. (2007). Multiple perspectives of fit in organizations across levels of analysis. In C. Ostroff \& T.A. Judge (Eds.), Perspectives on Organizational Fit (pp. 369). New York: Lawrence Erlbaum Associates.

Parker, S.K. \& Ohly, S. (2008). Designing motivating jobs: An expanded framework for linking work characteristics and motivation. In R.Kanfer, G.Chen \& R.Pritchard (Eds.), Work Motivation: Past, Present, and Future (pp. 233-284). New York: Routledge.

Parker, S.K., \& Sprigg, C.A. (1999). Minimizing strain and maximizing learning: the role of job demands, job control, and proactive personality. Journal of Applied Psychology, 84, 925939.

Patterson, M., West, M.A., Wall, T.D. (2004). Integrated manufacturing, empowerment, and company performance. Journal of Organizational Behavior, 25, 641-66.Rick, J., Thomson, L., Briner, R., O’Regan, S., Daniels, K. (2002). Review of existing scientific knowledge to underpin standards of good practice for key work-related stressors - phase 1. Sudbury: HSE Books.

Pomaki, G., \& Maes, S. (2002). Predicting quality of work life: From work conditions to selfregulation. In E. Gullone, \& R.A. Cummins (Eds.), The universality of subjective well- 
being indicators (pp. 151-173). Dordrecht, the Netherlands: Kluwer Academic Publishers.

Rimé, B. (2007). Interpersonal emotion regulation. In J.J. Gross (Ed.), Handbook of emotion regulation ( $\mathrm{pp}$ 466-485). New York: Guildford.

Rijk, de A.E., Le Blanc, P.M., Schaufeli, W.B., \& Jonge de, J. (1998). Active coping and need for control as moderators of the job-demand-control model: effects on burnout. Journal of Occupational and Organizational Psychology, 71, 1-18

Salvendy, G. (Ed.) (1998). Handbook of human factors and ergonomics. New York: Wiley.

Sargent, L.D., \& Terry, D.J. (1998). The effects of work control and job demands on employee adjustment and work performance. Journal of Occupational and Organizational Psychology, 71, 219-236.

Schaubroeck, J., \& Merritt, D.E. (1997). Divergent effects of job control on coping with work stressors: the key role of self-efficacy. Academy of Management Journal, 40, 738-754.

Schaubroeck, J., Jones, J.R., \& Xie, J.L. (2001). Individual differences in utilizing control to cope with job demands: Effects on susceptibility to infectious disease. Journal of Applied Psychology, 86, 265-278.

Schönpflug, W., \& Battmann, W. (1988). The costs and benefits of coping. In S.Fisher \& J.Reason (Eds.), Handbook of Life Stress, (pp. 699-713). Chichester: Wiley.

Scott, S.G., \& Bruce, R.A. (1994). Determinants of innovative behavior: A path model of individual innovation in the workplace. Academy of Management Journal, 37, 580607.

Shimazu, A., de Jonge, J. \& Irimajiri, H. (2008). Lagged effects of active coping within the demand-control model: A three-wave panel study among Japanese employees. International Journal of Behavioral Medicine, 15, 44-53. 
Shimazu, A., Shimazu, M., Odara, T. (2005). Divergent effects of active coping on psychological distress in the context of the Job Demands-Control-Support Model: The roles of job control and social support. International Journal of Behavioral Medicine, $12,192-198$.

Siegrist, J. (1998). Adverse health effects of effort-reward imbalance at work: Theory, empirical support, and implications for prevention. In C.L. Cooper (Ed.), Theories of organizational stress (pp. 190-204). Oxford: Oxford University Press.

Skinner, E.A., Edge, K., Altman, J., \& Sherwood, H. (2003). Searching for the structure of coping: a review and critique of category systems for classifying ways of coping. Psychological Bulletin, 129, 216-269.

Sonnentag, S., \& Natter, E. (2004). Flight attendants' daily recovery from work: Is there no place like home? International Journal of Stress Management, 11, 366-391.

Sonnentag, S., \& Niessen, C. (2008). Staying vigorous until work is over: The role of trait vigor, day-specific work experiences and recovery. Journal of Occupational and Organizational Psychology, 81, 435-458.

Sonnentag, S., \& Zijlstra, F.R.H. (2006). Job characteristics and off-job activities as predictors of need for recovery, well-being, and fatigue. Journal of Applied Psychology, 91, 330-350.

Taris, T.W., \& Kompier, M.A.J. (2005). Job demands, job control, strain and learning behavior: Review and research agenda. In A. Stamatios Antoniou, \& C.L. Cooper (Eds.), Research companion to organizational health psychology (pp. 132-150). London: Edward Elgar Press.

Tennen, H., Affleck, G., Coyne, J.C., Larsen, R.J., \& Delongis, A. (2006). Paper and plastic in daily diary research: Comment on Green, Rafaeli, Bolger, Shrout, and Reis (2006). Psychological Methods, 11, 112-118. 
Terry, D.J., \& Jimmieson, N.L. (1999). Work control and employee well-being: A decade review. In C.L. Cooper \& I.T. Robertson (Eds.), International Review of Industrial and Organizational Psychology, Volume 14 (pp. 95-148). Chichester: Wiley \& Sons.

Terry, D.J., Nielsen, M., \& Perchard, L. (1993). The effects of work stress on psychological well-being and job satisfaction: The stress buffering role of social support. Australian Journal of Psychology, 45, 168-175.

Toh, S.M., Morgeson, F.P., \& Campion, M.A. (2008). Human resource configurations: Investigating fit with the organizational context. Journal of Applied Psychology, 93, 864-882.

Tooren, van den M., \& Jonge, de J. (this volume). The role of matching job resources in different demanding situations at work: A vignette study. Journal of Occupational and Organizational Psychology.

Trougakos, J.P., Beal, D.J., Green, S.G., \& Weiss, H.M. (2008). Making the break count: An episodic examination of recovery activities, emotional experiences, and positive affective displays. Academy of Management Journal, 51, 131-146.

Vancouver, J.B. (2000). Self-regulation in organizational settings: A tale of two paradigms. In M. Boekaerts, P.R. Pintrich, \& M. Zeidner (Eds.), Handbook of Self-regulation (pp. 303-341). San Diego, CA: Academic Press.

Viswesvaran, C., Sanchez, J.I., \& Fisher, J. (1999). The role of social support in the process of work stress: A meta-analysis. Journal of Vocational Behavior, 54, 314-334.

Vohs, K.D., Baumeister, R.F., \& Ciarocco, N.J. (2005). Self-regulation and self-presentation: Regulatory resource depletion impairs impression management and effortful selfpresentation depletes regulatory resources. Journal of Personality and Social Psychology, 88, 632-657. 
Wall, T.D., Jackson, P.R., Mullarkey, S., \& Parker, S. (1996). The demands-control model of job strain: A more specific test. Journal of Occupational and Organizational Psychology, 69, 153-166.

Wood, S. (1999). Human resource management and performance. International Journal of Management Reviews, 1, 367-413 Wrzesniewski, A., \& Dutton, J. (2001). Crafting a job: Revisioning employees as active crafters of their work. Academy of Management Review, 26, 179-201. 